\title{
KAMPUNG DEVELOPMENT TOWARD SMART CITY
}

Tanti Satriana Rosary Nasution*, Purwanita Setijanti*, Asri Dinapradipta*, Angger Sukma Mahendra*, Susetyo Firmaningtyas**, Muhammad Ainul Yaqin**

*) Department of Architecture, Institut Teknologi Sepuluh Nopember, Kampus ITS Sukolilo, Surabaya 60111

**) Laboratory for Housing and Human Settlement, Department of Architecture, Institut Teknologi Sepuluh Nopember, Kampus ITS Sukolilo, Surabaya 60111 e-mail: tantisatriana@gmail.com

\begin{abstract}
Surabaya was developed from maritime activities which lead to trade and industrial activities. These activities resulted in the forming of settlements known as kampung. Kampung became an important part in the development of a city because this area has become a place for the low and middle-income people to grow and work. However, the rapid development of Surabaya towards a more modern city brings struggle for kampungs in Surabaya to exist. Long-established kampung such as Kampung Kaliasin is pressured by the city development as well as urban socioeconomic mobility that its condition is slowly degrading. The pressure from the surrounding environment is overwhelming not only in social and economic issues but also in environmental issues (climate, sanitation, greenings, etc.). Surabaya City Government overcomes those problems by carrying the concept of Smart City Surabaya. This paper aims to identify how the development of urban kampung, in this case Kampung Kaliasin, in the direction of Smart City Surabaya. The method used is descriptive qualitative method. The variables studied are aspects of smart city which is analysed in relation with the readiness of urban kampung that continues to develop toward Smart City Surabaya. The result shows that Kampung Kaliasin has started to promote smart city concept in their daily activities: public participation which indicates Smart Government, ICT marketing in residents' businesses as part of Smart Economy, public facilities provision to support Smart Living, pluralism and openness which indicates Smart People, and the use of public transportation to promote Smart Mobility.
\end{abstract}

Keywords: kampung, smart city, Surabaya

\section{INTRODUCTION}

Surabaya is the capital of East Java province that has a diversity of activities ranging from economic, social and cultural activities. Because of the concentration of these 
activities, Surabaya became one of the cities of choice to dwell and live for its people. Traced back to its history, Surabaya can be considered as kampung city (Silas, 2011). Kampung has major contribution in housing provision, as it provides $70-85 \%$ housing in a city (Kemenpera, 2010). It has become a place where settlers and/or migrants stay and make a living.

Smart City is defined as a city capable of using human capital, social capital, and modern telecommunications infrastructure to realize sustainable economic growth and high quality of life, with prudent resource management through community-based governance. (Caragliu, A., Et al in Schaffers, 2010). Kourtit \& Nijkamp (2012) revealed that Smart City has become a landmark in town planning. According to Nam \& Pardo (2011), the concept of smart city not only base the development and management of cities in the technological dimension, but also includes the human and institutional dimension. This concept is shown in Figure 1.

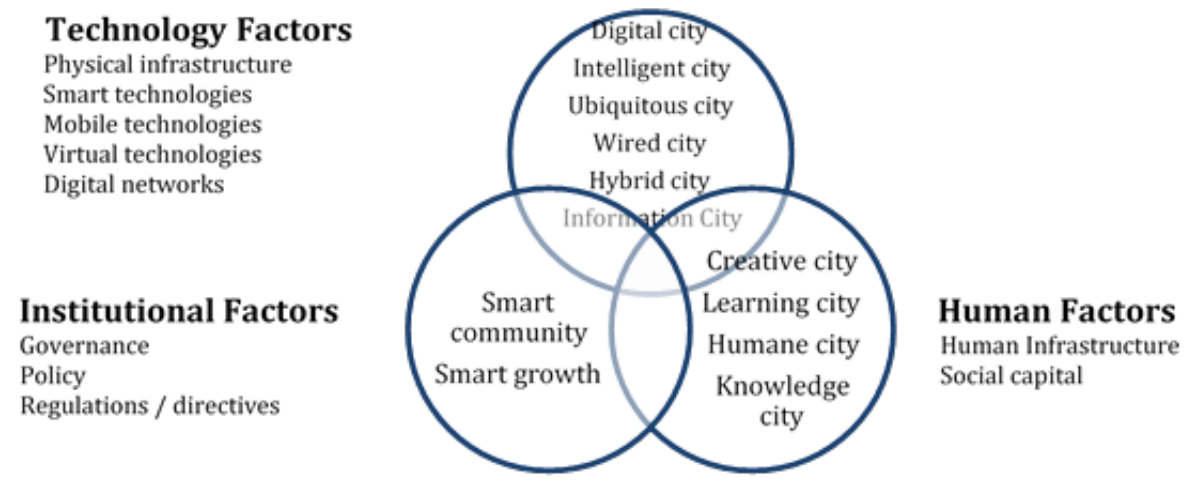

Figure 1. Basic Component of Smart City Source: Nam \& Pardo, 2011

Cities called smart city initially had a new breakthrough in problem-solving in their city, the development of these cities towards the smart city. Based on Networks European Technology Platform 2011 in Smart City Applications and Requirements, a city is classified as smart city if it has 6 criteria, namely:

1. Smart Economy (Competitiveness)

2. Smart People (Social and Human Capital)

3. Smart Governance (Participation)

4. Smart Mobility (Transport and ICT)

5. Smart Environment (Natural Resources)

6. Smart Living (Quality of Life)

\section{THEORY AND METHOD}

The method used in identifying the development of urban kampong towards Smart City Surabaya is historic-descriptive with qualitative methods. Descriptive is a method in researching a group of people, an object, a condition, a system of thought 
or a class of events in the present (Nazir, 1988). Descriptive research studies the problems in society, as well as the prevailing procedures in society and particular situation, including relationships, activities, attitudes, views, and ongoing processes and influences of a phenomenon. In this study, it is associated with the aspect of the formation of dwelling space and environment. The data used is qualitative data collected through field observation. Thus, the method applied is descriptive qualitative. Variables studied have been determined beforehand and they will be used to analyse the aspects in the history of development and movement of kampung in Surabaya towards Smart City Surabaya.

\section{Data Collecting}

The quality of data collection is related to the precision of the means used to collect data. Technique of collecting data was as follows:

1. Literature Review

2. Interview and Survey

3. Observation

4. Documentation

\section{RESULTS \& DISCUSSION}

Field surveys have been conducted in Kampung Kaliasin Surabaya, Tegalsari Subdistrict, Surabaya. Various types of dwellings can be found in this area, ranging from row houses, single house, Home Based Enterprises (HBEs), SOHOs, to luxury apartments. Various trade/services are also existed in this area, ranging from street vendors, small merchants, small shop to supermall. From field observations and interviews with residents of Kampung Kaliasin (Figure 2), the initial analysis results obtained are as follows:

\section{Competitiveness}

Most of the respondents have their own business, either as main source of income or additional income (Figure 3). Their businesses are mainly triggered by the market opportunities of their surroundings. Those businesses can be categorized as follows:

1. Service scale: urban, district/sub-district, kampung

2. Business break-even point: Sustained/long-term enterprises such as renting out rooms for workers, mid-term such as grocery stores, to short-term such as making snacks usually conducted by housewives.

From the description above, economic activities undertaken by kampung residents have a turnover that varies from Rp. 1 Million to Rp. 30 million. Most of the business activities of residents have a high dependence with economic activities in the outer ring of the kampung. 


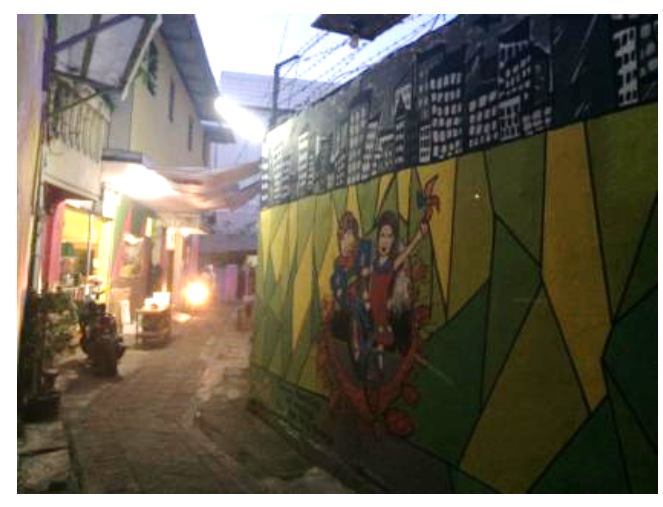

Figure 2. An Alley in Kampung Kaliasin Source: Field survey, 2017

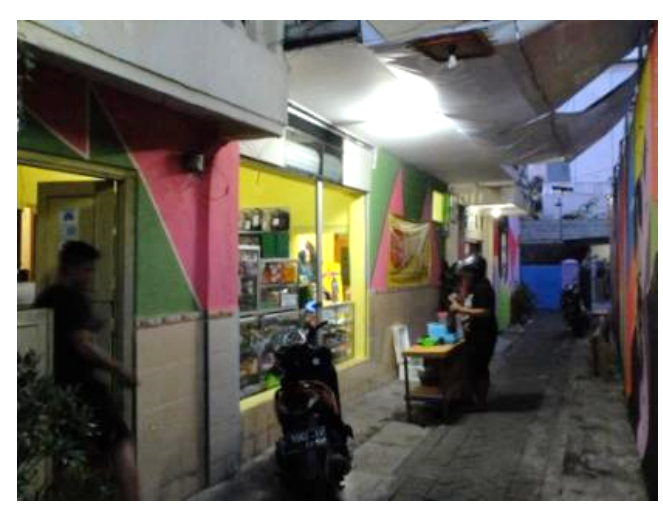

Figure 3. One of Home Based Enterprises at Kampung Kaliasin, Creating A Space by Adding Non-Permanent Tent to Cover the Alley Source: Field survey, 2017

\section{Social and Human Capital}

Residents of Kampung Kaliasin are in plural community, seen from many temporary shelters for workers around the area. Residents flexibility in accepting newcomers is shown, among others, by accommodating the activities of migrants which crowded at certain hours. On the other hand, residents also make regulations for the comfort and order of the residential environment (Figure 4). 


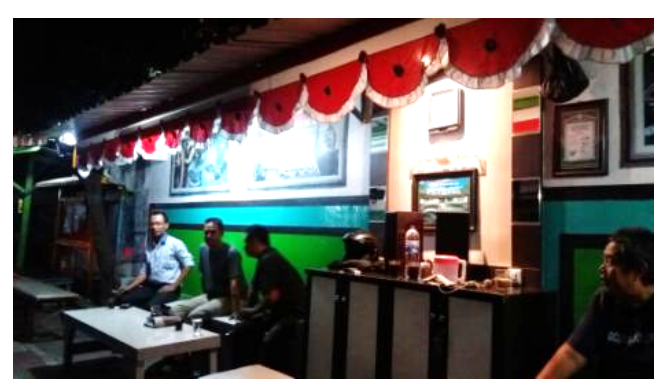

Figure 4. One Corner of Common Space Used by Male Residents to Maintain Kampung Kaliasin's Security Source: Field survey, 2017

\section{Participation}

At the lowest level, as previously stated, residents participate in maintaining the environment and social order in kampung and are actively involved in various social organizations. At a higher level, residents channel their aspirations through the Head of RT and then the head of RW. At an even higher level, although not actively participating, residents are taking notes of the growth and development of Surabaya and have opinions related to the development of their kampung and the city.

\section{Transport and ICT}

All respondents have private vehicles, mostly motorcycles, yet some still use the public transportation (bemo) as a means of transportation. The reason for using private vehicles lies in the aspect of high flexibility, in terms of time and route. In terms of communication, besides meeting directly, contact with other parties is also done by using phone and internet. Almost all respondents have often used the internet, both accessed from public places (coffee shops, etc.) and through personal access (mobile phone).

\section{Natural Resources}

One of the characteristics of Surabaya urban kampung is the high density of the building. Almost all respondents stated that the open space in their residential neighbourhood (shown in Figure 5) is scarce because the developed/built area is larger than the unbuilt area. Few houses have a small yard in front of the house. Rows of houses in the alley causes the houses only have openings on one side of the building, which is in the front. This condition will also affect the vulnerability of this kampung to the risk of fire spreading in case of fire. 


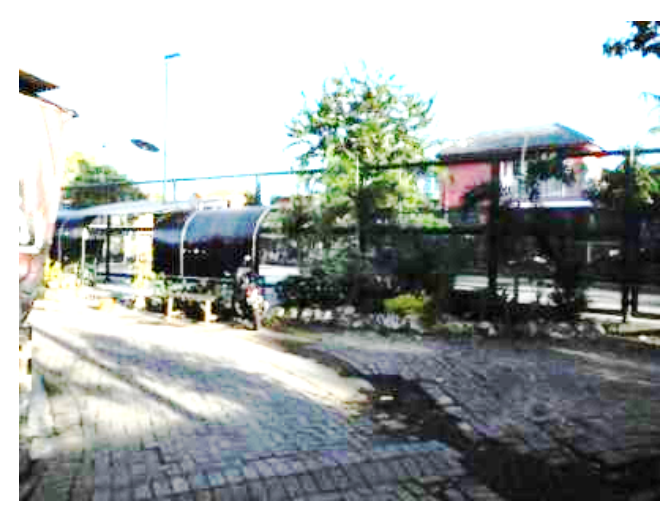

Figure 5. Open Space in Kampung Kaliasin Source: Field survey, 2017

\section{Quality of Life}

The quality of settlement in Kampung Kaliasin is quite good, clean and orderly. Kampung's friendly culture is still very visible, in contrast to the residential real estate area whose environment tends to be quiet. In many corners of Kampung Kaliasin, it is common to find residents who gather/discuss the problems of their kampong (Figure 6).

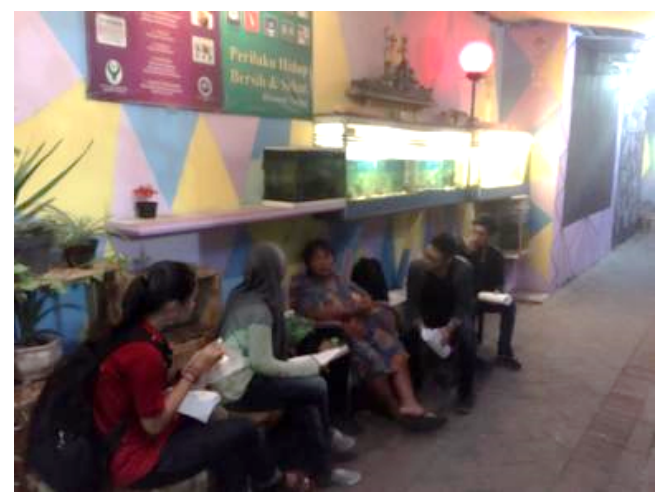

Figure 6. Semi-Private Spaces Built in Public Spaces, belong to and can be Used by All Residents Source: Field survey, 2017

Although residents of Kampung Kaliasin have relatively limited space and economic condition, their quality of life is supported by public spaces used for various social activities. This indicates a good social relationship in the community. 


\section{CONCLUSION}

The development of the urban kampung towards Surabaya Smart city grows rapidly in Kampung Kaliasin. This is caused by continuous aspects between competitiveness, social and human capital, participation, transport and ICT, natural resources and quality of life occurred in it. Although Kampung Kaliasin is so dense, its residents have started to promote smart city concept in their daily activities. In Smart Economy, some residents who have businesses such as food and snack, shoes and boarding houses already use ICT to market their products. Not all business owners use ICT because their daily turnover and demands are already high. For certain events, city government selects Kampung Kaliasin as an example of kampung with independent businesses. Likewise, in terms of Smart Living, in some empty lands or that included in public facilities, parks have been built so there are public spaces that can be used by surrounding inhabitants to socialize. Besides, some corner of this kampung is used as open spaces with free access to the internet that they can use free internet. This program is initiated by Surabaya government to support the kampung towards Surabaya Smart City.

\section{REFERENCES}

Kementerian Perumahan Rakyat (2010), Rencana Strategis Kementrian Perumahan Rakyat Tahun 2010-2014

Kourtit, K. and Nijkamp, P. (2012). Smart cities in the innovation age. Innovation: The European Journal of Social Science Research, 25(2), pp.93-95.

Nam, T. and Pardo, T.A. (2011), Conceptualizing Smart City with Dimensions of Technology, People, and Institutions. The Proceedings of the 12th Annual International Conference on Digital Government Research. Derived from https://www.ctg.albany.edu/publications/journals/dgo_2011_smartcity/dgo_ 2011 smartcity.pdf.

Nazir, M. (1998). Metode penelitian. Jakarta: Ghalia Indonesia.

Schaffers, H., Komninos, N., Pallot, M., Trousse, B., Nilsson, M. and Oliveira, A. (2011). Smart Cities and the Future Internet: Towards Cooperation Frameworks for Open Innovation. The Future Internet, pp.431-446.

Silas, J. (2011), Kampung Surabaya Menuju Abad XXI, Bappeko Kota Surabaya 
Nasution, Setijanti Dinapradipta Mahendra, Firmaningtyas, Yaqin : KAMPUNG DEVELOPMENT TOWARD SMART CITY

This page is intentionally blank 